\title{
Choice of Language in Bilateral Treaties: Fifty Years of Changing State Practice ${ }^{1}$
}

\author{
John King Gamble* \\ Charlotte $K u^{* *}$
}

\section{INTRODUGTION}

Treaties and treaty-making deservedly occupy a central place in the international legal scholarly literature. As the major source of international obligation, examining the form and content of treaties can provide tangible and quantifiable information about the behavior of states and the international environment in which they operate. On a more immediate level, treaties serve as a means for interstate communication. The language in which treaties are written affects how widely and deeply treaty obligations are understood and, hence, followed.

Dozens of books and articles have concerned the genre of treaties ${ }^{2}$ and literally hundreds of pieces have focused on specific treaty-related

1. A discussion in 1982 with Professor Peter H. Rohn, Director of the University of Washington's Treaty Research Center, planted the seeds for this work. Professor Rohn also commented on portions of an earlier draft of this paper and has discussed these issues with us. We wish to acknowledge the research assistance of Kyle L. Hannon, Angela Carone, Lisa Howells, Vicky Kohlmeyer, Sheryl Sivavec, Terri Thomas-Mack, and Andy Watson.

* Professor of Political Science, The Behrend College, The Pennsylvania State University.

** Deputy Executive Director, American Society of International Law.

2. See Arnold MaNair, The Law of Treaties (1961) for the most comprehensive coverage on the genre of treaties in the English language. See also SuzAnNE Bastid, Les traités dans la vie internationale (1985); Francesco Capotorti, Convenzione di Vienna sul diritto dei trattati (1969); Ingrid Detter, Essays on the Law of Treaties (1976); Taslim O. Elias, The Modern Law of Treaties (1974); A. Frangulis, Thérie et practique des traités internationaux (1934); Gyorgy Haraszti, Some fundamental Problems of the Law of Treaties (1973); Myres McDougal et al., The Interpretation of Agreements and World Public Order (1967); Paul Reuter, Introduction au droit des traités (1972); Shabtai Rosenne, Developments in the Law of Treaties, 1945-1986 (1989); and Shabtai Rosenne, The Law of Treaties: A Guide to the Legislative History of the Vienna Convention (1973). 
issues $^{3}$ or categories of treaties. ${ }^{4}$ Considerable scholarly attention has been paid to the legal and logistical problems attendant with using more than one language as official text of a treaty:

If the two can, without violence to the language, be made to agree, that construction which establishes this conformity is to prevail. In case they cannot be made to harmonize, other rules of construction must be resorted to for the purpose of determining, if possible, the common intention of the parties. ${ }^{5}$

3. See, e.g., , Effective Negotiation: Case Studies in Conference Diplomacy (Johan Kaufman ed. 1989); Oscar Schachter, Towards Wider Acceptance of UN Treaties (1971); Robert B. Stewart, Treaty Relations of the British Commonwealth (1939); M.T.Z. Tyau, The legal Obligations arising Out of Treaty Relations Between China and Other States (1917); Mark E. Villiger, Customary International Law and Treaties (1985); Hans Blix, The Requirement of Ratification, 30 BRIT. Y.B. INT'L L. 356 (1953); Maarten Bos, Theory and Practice of Treaty Interpretation, 27 Neth. Y.B. INT'L L. 3 (1980); Michael Brandon, The Validity of Unregistered Treaties, 29 BRIT. Y.B. INT'L L. 186 (1952); J.E.S. Fawcett, Treaty Relations of British Overseas Territories, 26 BRIT. Y.B. INT'L L. 86 (1949); John King Gamble, Reservations to Multilateral Treaties: A Macroscopic View of State Practice, 74 AM. J. OF INT'L L. 372 (1980); Michael J. Glennon, The Senate Role in Treaty Ratification, 77 AM. J. INT'L L. 257 (1983); Manley O. Hudson, Reservations to Multipartite Instruments, 32 AM. J. INT'L L. 330 (1938); Donald M. McRae, The Legal Effect of Interpretive Declarations, 49 BRIT. Y.B. INT'L L. 155 (1978); Martin A. Rogoff, The International Legal Obligations of Signatories to an Unratified Treaty, 32 Me. L. REv. 269 (1980); Shabtai Rosenne, The Depository of International Treaties, 61 AM. J. INT'L L. 923 (1967).

4. See, e.g., Hungdah Chiu \& Douglas M. Johnston, The People's Republic of China and the Law of Treaties (1972); The Hague Conventions and DeclaRations of 1899 and 1907 (James Brown Scott ed. 1915); Robert Hudec, Developing Countries in the GatT legal System (1987); Natalie H. Kaufman, Human Rights Treaties and the Senate (1990); John V.A. MacMurray, Treaties and Agreements With and Concerning China, $1894-1919$ (1921); Antoine Pillet, Les Conventions de la Haye (1918); Robert M. Slusser \& Jan F. Triska, The Theory, Law and Policy of Soviet Treaties (1962); Kenneth Vandevelde, United States Investment Treaties (1992); Robert Wilson, U.S. Commercial Treaties and International LAw (1960); Philip Alston, U.S. Ratification of the Covenant of Economic, Social and Cultural Rights, 84 Am. J. Int'L L. 365 (1990); R.R. Baxter, The Geneva Conventions before the U.S. Senate, 49 Aм. J. INT'L L. 550 (1955); John King Gamble, Post World War II Treaty-Making: The Task of the Third UN Law of the Sea Conference in Perspective, 17 SAN Diego L. Rev. 527 (1980); Pierre-Henri Imbert, La France et les traités relatifs au droit de l'homme, 26 Annuaire français de Droit international 31(1980); Arnold McNair, The Functions and Differing Legal Character of Treaties, 11 BRIT. Y.B. INT'L L. 100 (1930); Bernard H. Oxman, The Third U.N. Conference on the Law of the Sea: The Tenth Session (1981), 76 АM. J. INT'L L. 1 (1982).

5. Samuel B. Crandall, Treaties: Their Making and Enforgement 389 (2d ed. 1916). 
In'consistency between languages creates many problems. The solution suggested by the Vienna Convention on the Law of Treaties, however, is not altogether satisfactory:

1. When a treaty has been authenticated in two or more languages, the text is equally authoritative in each language, unless the treaty provides or the parties agree that, in case of divergence, a particular text shall prevail. . . 3. The terms of the treaty are presumed to have the same meaning in each authentic text. 4 . . . when a comparison of the authentic texts discloses a difference of meaning ... the meaning which best reconciles the texts, having regard to the object and purpose of the treaty, shall be adopted. ${ }^{6}$

Of course, many problems arise when the treaty does not have the same meaning in different languages. Samuel B. Crandall provides a fascinating discussion of numerous cases where a seemingly minor difference in wording between languages created serious problems once the treaties were implemented.' David P. O'Connell describes a solution suggested in 1924 by the World Court: "[w]hen a treaty is in two languages, and there is a discrepancy between them, each party is only bound by the meaning of the text in its own language." Both solutions do little to resolve conflicts. ${ }^{8}$

The focus of this article is a different aspect of language in treaties - the choice of language or languages as official text or texts of bilateral treaties. Some research has addressed the broader issue of multiple use of languages in international organizations and multilateral treaties, ${ }^{9}$ but bilateral treaties have received scant attention. This inattention likely stems from the difficulty of examining the treaty practice of more than 150 states in tens of thousands of treaties, a difficulty now largely overcome by modern database management techniques. This article examines a lengthy period of state practice, the half century between 1920 and 1970, in order to describe and understand language choices. At first blush, this may seem like much ado about nothing. Of course, it is the content, not the choice of official text, that matters most.

6. Vienna Convention on the Law of Treaties, May 23, 1969, art. 33, 63 AM. J. INT'L L. 875, 886 (1969) [hereinafter Vienna Convention].

7. Crandall, supta note 5 , at 389-93.

8. David P. O'Connell, International Law 258 (2d ed., vol. 1, 1970). See Mavrommatis Concessions, 1924 P.C.I.J. (Ser. A) No. 2, at 19.

9. Mala Tabory, Multilingualism in International Law and Institutions (1980). 
However, the approach taken here, based as it is on an enormous amount of state practice, can elucidate a number of important issues:

- To what degree has English taken over the lingua franca $^{10}$ role previously played by Latin and French?

-Is there any political dimension to language choice?

- Has the rise of the United States and the Soviet Union as superpowers after World War II been accompanied by an increased use of English and Russian as official texts?

-Is the emergence of the Third World as a major force in the international system reflected in languages used in treaties?

\section{The "Conventional" Wisdom about Official Text}

No doubt the treaty power claimed by all states includes the right to use their languages as official texts of the treaties to which they are party. Although the Vienna Convention does not deal explicitly with the issue, it is inconceivable that any state lacks the power to have its national language(s) used as an official text of a bilateral treaty. Lord Arnold McNair stated simply that "parties are free to choose the language or languages in which a treaty is expressed." "11

Aside from the assertion that states may use whatever official texts they wish in their treaties, the most frequent focus of work on language choice concerns the use of lingua franca:

Until the eighteenth century the common language, or lingua franca, of diplomacy was Latin. Not only did diplomats write to each other in Latin but they even conversed in that medium. Such treaties as those of Westphalia (1648), the Anglo-Danish Treaty of 1670, and the Anglo-Dutch Treaty of 1674 were all drafted and signed in Latin and that was in fact the general practice. ${ }^{12}$

Latin was the language of most treaties " $[u]$ ntil about the beginning of the eighteenth century," 13 although Mala Tabory found an exception in that "towards the end of the fifteenth century, Castilian Spanish

10. The term, lingua franca, will be used here because it is so widely understood. Some prefer "third language," but that is easily confused with those treaties that have three different languages as official texts.

11. Arnold McNair, The Law of Treaties 30 (1961).

12. Harold G. Nicolson, Diplomacy 231 (1939).

13. Charles C. Hyde, International Law: Chiefly as Interpreted and Applied by the United States 1422 (1945). 
was the diplomatic idiom in many courts." 14 Eventually, Latin was replaced by French due to "the political ascendancy of France under Louis XIV." ${ }^{15}$ However, others were quick to assert that the position enjoyed by the French language was at most indirectly related to the military, diplomatic, and political successes of France. More than half a century ago, James Brown Scott noted that linkages between national, economic, and political power and language are at most indirect:

Le grec est devenu la langue du commerce intellectuel quand la Grèce est descendue à l'état d'une province romaine. Il est devenu même la langue d'une civilisation mondiale sous l'empire d'Auguste et pendant les premiers siècles de notre ère, pendant lesquels ses successeurs ont dominé le monde, brisant toute opposition matérielle, imposant et leur volonté et leurs lois. Ni la puissance militaire, ni le prestige immense de l'Empire ne réussirent à remplacer le grec de l'Orient par le latin. ${ }^{16}$

Even less tenable are the numerous assertions on the intrinsic superiority of the French language. Harold G. Nicolson stated that French "possesses qualities which enable it to claim precedence over others for all purposes of diplomatic intercourse." 17 Scott, a francophone of René Lévesque (Quebec separatist leader) proportions, believed that the use of French could overcome the foreign mind-set and avoid misunderstandings and ambiguity. ${ }^{18}$ Manley O. Hudson took Scott to task, albeit politely, pointing out that in the immediate post-World War I period, English was used increasingly. ${ }^{19}$ Perhaps the most ambitious claim made on behalf of the French language was:

It is impossible to use French correctly without being obliged to place one's ideas in the proper order, to develop them in a logical sequence, and to use words of almost geometrical accuracy. If precision is one of the major virtues of diplomacy, it may be regretted that we are discarding as our medium of

14. TABORY, supra note 9 , at 4 .

15. Lassa Frances L. Oppenheim, International Law: A Treatise $771(\mathrm{H}$. Lauterpacht ed., 8th ed. 1955). (1924).

16. James Brown Scott, Le Français, langue diplomatique moderne 129

17. Nicolson, supra note 12 , at 234 .

18. Scotr, supra note 16 , at 1 .

19. Manley O. Hudson, Languages Used in Treaties, 26 AM. J. INT'L L 368 (1932). 
negotiation one of the most precise languages ever invented by the mind of man. ${ }^{20}$

Writing almost fifty years later, Leslie Green reached entirely the opposite conclusion: "There is, of course, nothing linguistically special about either the French or English languages which warrants special treatment. Indeed, there are no scientific grounds for thinking that any human language is better, either in general or for some special purposes, than any other." 21

Regardless of the dominant role played by French, states insisted that the use of French was a matter of convenience, not a legal requirement. ${ }^{22}$ This sentiment was expressed even at the time of the Congress of Vienna when French was pre-eminent:

Article 120 of the General Treaty of the Vienna Congress of 1815 expressly observes that the fact of the French language having been exclusively employed in all copies of that treaty is not to be construed into a precedent for the future, and that every Power reserves the right to adopt, in future negotiations, and conventions, the language which it had previously employed in diplomatic relations. ${ }^{23}$

Commentators generally agree about when French was overtaken by English as the model diplomatic language. "French has lost its dominant position as the diplomatic language and, since 1919, English has become at least as important." 24 The Paris Peace Conference in 1919 appears to have been the first time that English and French were on an equal footing. ${ }^{25}$ In the period since World War II, two dominant trends have emerged in language choice. First is the increased use of English where a lingua franca is employed. Second (generally regarded as the prevailing practice) is the practice of preparing "versions of the treaty in both languages. . . ."26 United States practice early abandoned French in favor of making English one of the official texts:

20. Nicolson, supra note 12 , at 234.

21. Leslie Green, Are Language Rights Fundamental?, 25 Osgoode Hall L. J. 639 , at 662 (1987).

22. John Bassett Moore, A Digest of International Law 181-82 (vol. 5, 1906).

23. OpPenheim, supra note 15, at 771-72.

24. Edward D. Brown \& Georg Schwarzenberger, A Manual of InterNATIONAL LAw 129 (6th ed. 1976).

25. OPPENHEIM, supta note 15 , at $\mathbf{7 7 2}$.

26. Brown \& Schwarzenberger, supta note 24, at 129. 
Bilateral agreements concluded by the United States with other countries are usually drawn up in the English language and in the language of the foreign country, or in some other foreign language selected by it. The French language has frequently been the language selected. In a number of such agreements the English language has been the only language of the originals, while in some of the earlier agreements the English language was not used, but French, Spanish, Arabic, Turkish, or Portuguese, as the case might be, alone was used. ${ }^{27}$

John Bassett Moore cited a transmittal letter accompanying the 1785 consular treaty with France written by John Jay recommending that "in the future, every treaty or convention which Congress might think proper to engage in should be formally executed in two languages." ${ }^{28}$ In fact, the United States and the United Kingdom were among the first and most insistent upon using their national language in all their treaties. ${ }^{29}$

The position of the Soviet Union on language choice showed a certain ambiguity. On the one hand, Soviet advocacy of the Russian language because of its "inherent richness and beauty" 30 is reminiscent of pleas on behalf of French early in this century. In a different vein, Academician Korovin declared that "Soviet treaty practice strictly adheres to the principle of complete equality of languages of the contracting parties."'31

There are broader implications to these issues. Although linkages between national, economic, and political power and language are difficult to prove, the possibility of such linkages should not be overlooked. Why was Latin chosen as the language of diplomacy? It was the language of the university, the literati and of the Roman Catholic Church, whose support for any treaty could make violation costly. A more cynical explanation would hold that Latin was used to placate the church in a minor, pro forma way to divert attention from the content of treaties.

In the modern era, especially in democratic states, public opinion has become important in the negotiation and implementation of fair

27. Green H. Hackworth, Digest of International Law 37 (vol. 5, 1943).

28. MOORE, supra note 22 , at 180 .

29. Biswanath Sen, A Diplomat's Handbook of International Law and Practice 458-59 (1979).

30. Robert M. Slusser \& Jan F. Triska, The Theory, Law, and Policy of Soviet Treaties 61 (1962).

31. Id. at 60 . 
and equitable treaties, "open covenants openly arrived at.",32 The need to make treaties accessible to the public-at-large has clear implications for language choice. Nationalist aspirations, be they in 1648,1914 , or 1993, probably are the most potent political forces operating during this millennium. Language is a factor in virtually all of these nationalist movements. The choice of language in treaties can be a manifestation of important domestic political forces. Furthermore, language choice can be influenced by external factors such as hegemonic third parties and the need for a guarantor power.

\section{Categorizing State Pragtige}

The recent trend in bilateral treaties has been to make the language(s) of both party-states official languages of the treaty. ${ }^{33}$ For example, if the United States and Mexico conclude a bilateral agreement on border problems, both English and Spanish will be official texts. However, the most interesting cases arise when states opt for language choices different from this now-dominant pattern. This choice may take several forms, ${ }^{34}$ the most common of which are:

(i). the parties may opt for a convenient neutral language or lingua franca, e.g., Bulgaria and Greece employ French; ${ }^{35}$

(ii). the parties may decide to use the language of one of the parties as the only official language, e.g., U.S. and Sweden use English; ${ }^{36}$

(iii). other - there are examples that fit into neither (i) or (ii) but that combine them, e.g., Indonesia and Japan using Japanese, Indonesian, and English. ${ }^{37}$

Later this article shall deal with the more complicated situation arising when a language, e.g., English, both plays a lingua franca role and is the official language of one of the parties.

32. Kenneth N. Waltz, Man, the State, and War 95-103 (1959).

33. There are more complicated situations where a state may have more than one official language, e.g., Belgium, Canada, Finland, India, and Switzerland.

34. Blix and Emerson adopted a scheme for classifying language choice that consisted of a single authentic text, one of several authentic texts, several authentic texts, all texts equally authentic and all texts equally authentic (by implication). THE Treaty Maker's Handbook 254-57 (Hans Blix and Jirina H. Emerson eds., 1973). 145.

35. Sec, e.g., Payments Agreement, Dec. 5, 1953, Bulg.-Greece, 225 U.N.T.S.

36. See, e.g., Exchange of Notes Between the Governments of the United States of America and Sweden, concerning the denunciation of provisions No. 11 and 12 of the Consular Convention of June 1, 1910, June 18 and 29, 1920, Swed.-U.S., 2 L.N.T.S. 157.

37. See, e.g., Treaty of Peace, Jan. 20, 1958, Japan-Indon., 324 U.N.T.S. 227. 
It is a daunting task to examine a sizable number of treaties to determine what practice has actually been followed. Ironically, the research for this article could have been carried out more easily a decade ago. ${ }^{38}$ For purposes of this article, all bilateral treaties contained in the League of Nations Treaty Series (L.N.T.S.) and in the United Nations Treaties Series (U.N.T.S.) (those registered between 1945 and 1970) have been examined. This sample does not include all of the bilateral treaties signed during the period between 1920 and $1970,{ }^{39}$ but it does represent such a large number - and not a patently atypical sample - that we assume that it is representative of all treaties concluded during this fifty-year period. Before examining these treaties, it is important to get some grasp of the magnitudes involved:

Table 1

\section{TREATIES INCLUDED IN THE STUDY}

$\begin{array}{lccccc}\text { SERIES } & \text { YEARS } & \text { TOTAL } & \text { NO. / \% } \\ & \text { COVERED } & \text { NUMBER } & \text { BET. STATES } & \text { "RULES" } & \text { EXCEPTIONS } \\ \text { League } & 1920-42 & 4,900 & 4,410 / 90 & 2,427 / 55 & 1,983 / 45 \\ \text { UN } & 1945.69 & 10,035 & 8,128 / 81 & 7,069 / 87 & 1,059 / 13\end{array}$

Although Table 1 is fairly straightforward, some elaboration may prove helpful. This study includes nearly 15,000 treaties, the vast majority of which were signed between 1920 and 1970. Most of these treaties were bilaterals between states, however, some were multilateral treaties and bilaterals between a state and an international organization. The latter two categories have been excluded to avoid extraneous, complicating factors. In the case of the L.N.T.S., there are 4,410 bilateral treaties between states ( $90 \% \times$ the 4,900 total) of which $45 \%$ (or 1,983) fall into the category of principal interest here: those that have official texts that are not simply the official language(s) of the parties. In the case of the U.N.T.S., only $13 \%$ of the bilaterals fall into this category. Broadly speaking, about 15,000 treaties were ex-

38. The Treaty Research Center, established by Professor Peter H. Rohn at the University of Washington, collected information about most of the world's treaties and made it possible to answer questions such as those surrounding choice of official text. Regrettably, the Treaty Research Center is no longer in operation.

39. For example, there is the problem of the "gap"-treaties that were never registered with the League of Nations or with the United Nations. 
amined and approximately $20 \%(3,000)$ of them fell into this "exception" group of treaties using a language other than the official language(s) of the parties.

\section{Broad Patterns of Behavior}

One of the most conspicuous findings, evident from Table 1, is the marked increase in the proportion of standard fare cases, i.e., those using the official language(s) of both parties, from the League of Nations to the United Nations. For the L.N.T.S., $45 \%$ of bilateral treaties between states did something other than choose the languages of both parties-what we defined as "exception" nearly was the "rule." In the case of the U.N.T.S., the figure dropped to $13 \%$. This represents a marked change in behavior in a relatively short period of time. The reasons for this change will be examined principally by analyzing the $45 \%$ of the L.N.T.S. and the $13 \%$ of the U.N.T.S. that constitute exceptions as defined here. ${ }^{40}$

The first question one must ask about these treaties regards the number of official texts chosen. As Table 2 shows, almost all of these treaties $(95 \%)$ use only one language as official text. ${ }^{41}$ The others, the $5 \%$ using two official texts, are interesting, but represent such a small group that they can be dealt with separately almost on an individual basis.

Table 2

NUMBER OF OFFICIAL TEXTS ACCORDING TO SIGNATURE DECADE

NUMBER OF OFFICIAL TEXTS

\begin{tabular}{|c|c|c|c|c|c|}
\hline & & & & & \multirow{2}{*}{ TOTALS } \\
\hline & & GND & $17 \mathrm{~V}$ & & \\
\hline DECADE & $1920 \mathrm{~s}$ & 1024 & 63 & 0 & 1087 \\
\hline TREATY & 1930s & 841 & 48 & 0 & 889 \\
\hline WAS & $1940 \mathrm{~s}$ & 112 & 3 & 0 & 115 \\
\hline
\end{tabular}

40. A more satisfactory approach would have been to examine all bilateral treaties and to compare the "exceptions" to the "rules." This was feasible only for three "case studies," Canada, China, and Japan, discussed infra at Part V.

41. It must be remembered that this group of treaties contains only the "exceptions," those that do not have both countries' languages as official texts. If all bilaterals were included, most would have two official texts. 
SIGNED

$\begin{array}{lrr}1950 s & 284 & 13 \\ 1960 s & 612 & 32 \\ \text { TOTALS } & 2873 & 159\end{array}$

130

$159 \quad 1$

The next question to be addressed is which languages have been used in these 3,033 treaties. This information is contained in Table 3.

Table 3

FREQUENCIES OF LANGUAGES AS OFFICIAL TEXTS

$($ TOTAL $=3,194)$

$\begin{array}{lrlr}\text { ARABIC } & 1 & \text { GERMAN } & 119 \\ \text { AFRIKAANS } & 1 & \text { ITALIAN } & 13 \\ \text { CHINESE } & 1 & \text { JAPANESE } & 4 \\ \text { CZECH. } & 1 & \text { NORWEG. } & 3 \\ \text { DANISH } & 4 & \text { PORTUG. } & 26 \\ \text { DUTCH } & 3 & \text { RUSSIAN } & 6 \\ \text { ENGLISH } & 903 & \text { SPANISH } & 63 \\ \text { FRENCH } & 2009 & \text { SWEDISH } & 6\end{array}$

Sixteen different languages were used at least once, but English, French, and German account for $97 \%$ of the cases. Figure 1 shows the relative proportion of English, French, and German ${ }^{42}$ over the fifty year period. In the earliest decades, German occupied a small, but significant, position. After World War II, German almost disappeared as a language in bilateral treaty-making except, of course, in the usual two language cases and between German-speaking countries.

The relative importance of English and French could hardly be more striking. Before World War II, French accounted for approximately $80 \%$ of the treaties. The most recent data available (the 1960s) show that the frequencies of English and French have reversed with English now accounting for almost $80 \%$ of treaties.

No satisfactory way exists to account in the data for an official text acting both as lingua franca and as the national language of one of the parties. This problem is most acute for the United States and English. The United States is clearly the most prolific treaty maker in the world ${ }^{43}$ and also insists on the use of English in virtually all of its

42. The incidence of other languages is too small to be represented on the graph.

43. Peter H. Rohn, Treaty Profiles 244-45 (1976). 
Figure 1

PERGENTAGE OF TREATIES BY LANGUAGE BY DECADE (TOTAL $=2,943$ )

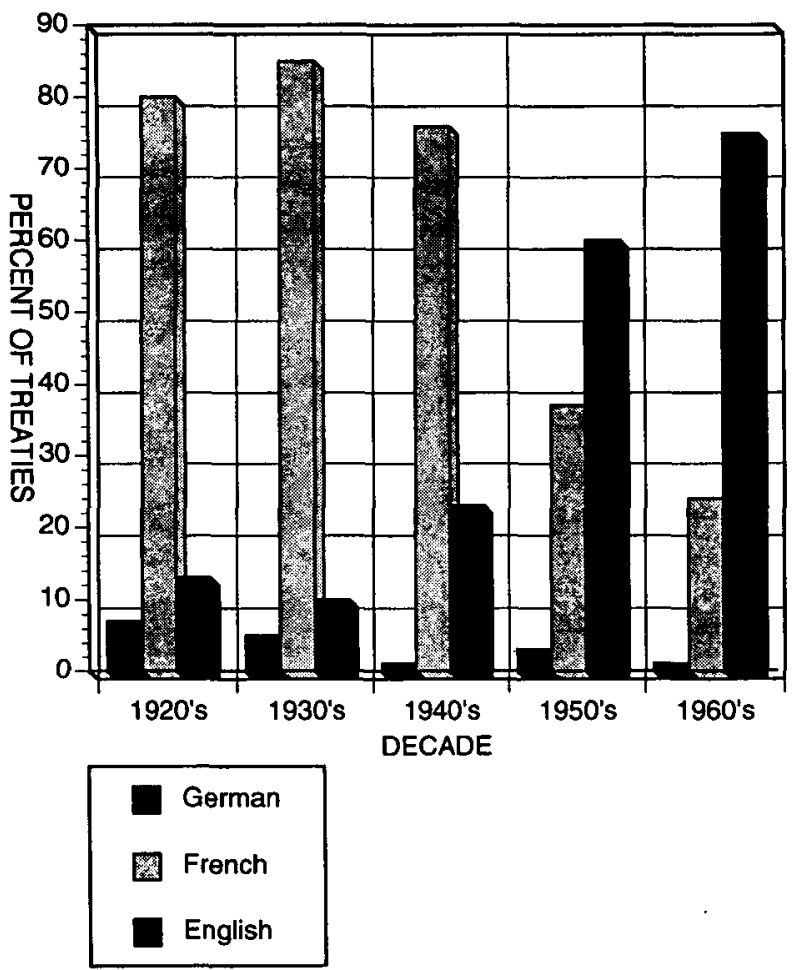

treaties. How can one determine the extent to which the dominance of English since World War II is due to the power and influence of the United States, to the ascendancy of the English language or whether the two factors are inseparable? It would be fascinating to try to resolve this matter by carefully controlling for each factor, perhaps even quantifying differences between languages. For example, consider the cases of Romania and the Netherlands. Since Dutch and Romanian are used by relatively few people, there is virtually no chance that either will be used as a lingua franca. One might assume that Romania would prefer to use French as a lingua franca while the Netherlands would opt for English because of relative linguistic proximities, Romanian to French and Dutch to English. 
Figure 2

PERCENTAGE OF TREATIES BY LANGUAGE BY DECADE (EXGLUdes TREATIES WITH OFFICIAL TEXT SAME AS NATIONAL LANGUAGE OF EITHER PARTY)

$($ TOTAL $=1601)$

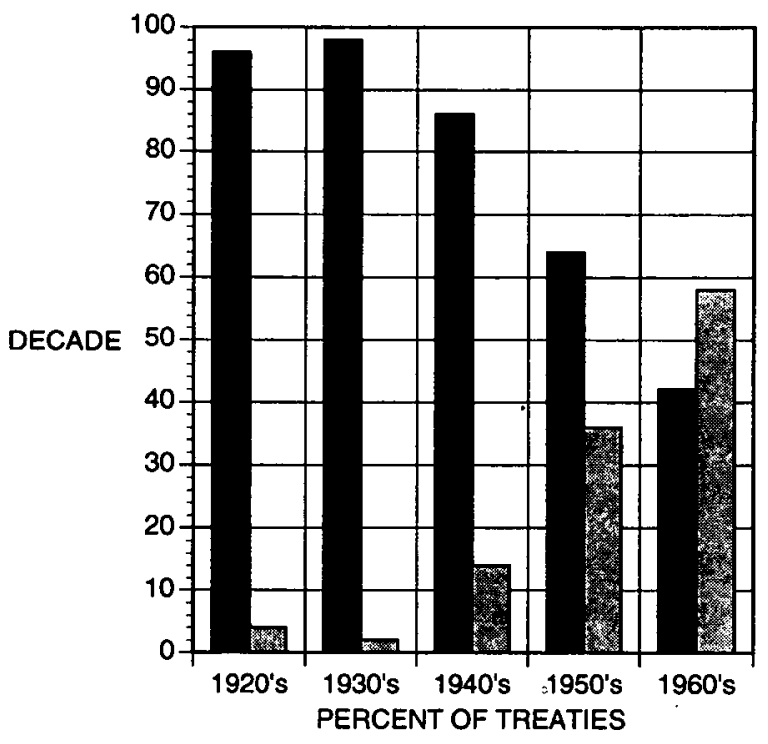

French

English

Figure 2 provides one way of addressing the problem of the inseparability of the lingua franca and dominant party roles played by languages. The figure includes those treaties that use only one language as official text and for which that language is the national language of neither party. Thus, any possible direct effects the United States would have on the greater use of English, France on the greater use of French, etc., have been removed. The dominance of English over French is not as marked as in Figure 1, but the fifty-year shift is strong and clear. During the 1920 s, French accounted for $95 \%$ of these treaties and English only $4 \%$. By the 1960 s, English stood at $56 \%$ while French had dropped to $41 \%$.

The large quantity of treaties included in this study limited the amount of information collected about each treaty except, of course, for the most basic attributes: signature date, force date, parties, languages, and a general categorization of the subject matter (i.e., political, diplomatic, economic, cultural, military, and humanitarian). One could 
disagree about where a particular treaty should fall, but the categories were applied uniformly.

Table 4 must be interpreted with great care due to the small numbers, especially in the case of German and the co-existence of two different factors, topic category and time. Since French dominated the pre-World War II years, it is difficult to determine if the subject matter of those treaties is due more to the era or to a tendency for the French language to be used more when certain subjects are negotiated. Overall, the clearest finding is a negative one. There is not much difference among French, English, and German for the major topic categories.

Table 4

\section{FREQUENCIES OF LANGUAGES BY TOPIC} $($ TOTAL $=2,908)$

$\begin{array}{lccc} & \text { English } & \text { French } & \text { German } \\ \text { DIP. } & 294 & 988 & 60 \\ & 34 \% & 51 \% & 54 \% \\ \text { CUL. } & 26 & 25 & 1 \\ & 3 \% & 1 \% & 1 \% \\ \text { ECON. } & 395 & 844 & 39 \\ & 46 \% & 44 \% & 35 \% \\ \text { HUM. } & 8 & 3 & 0 \\ & 1 \% & <1 \% & 0 \% \\ \text { MIL. } & 29 & 35 & 11 \\ & 4 \% & 2 \% & 10 \% \\ \text { POL. } & 114 & 36 & 0 \\ & 13 \% & 2 \% & 0 \% \\ \text { TOTALS: } & 866 & 1931 & 111 \\ & 100 \% & 100 \% & 100 \%\end{array}$

While Table 2 shows the infrequency of treaties with more than one official text, Table 5 illustrates changes over time. Except for the atypical decade of the 1940 s, there is remarkable consistency.

Table 5

PERCENTAGE OF TREATIES WITH MORE THAN ONE OFFICIAL TEXT

$\begin{array}{lrrrrr}\text { DECADE: } & 1920 \mathrm{~s} & 1930 \mathrm{~s} & 1940 \mathrm{~s} & 1950 \mathrm{~s} & 1960 \mathrm{~s} \\ \text { \% WITH MORE } & 5.8 \% & 5.4 \% & 2.6 \% & 4.4 \% & 5.0 \%\end{array}$


Another way to approach the treaties with two official texts is to examine language dyads, i.e., pairs of languages. With sixteen different languages represented, a total of 120 possible dyads exists. Most of the dyads were never used. This is hardly surprising-one would not expect to find Chinese and Irish as official texts in an agreement other than one between China and the Republic of Ireland. It might be interesting to look at very small dyads, for example, Chinese/English, ${ }^{44}$ Italian/ Russian, ${ }^{45}$ and English/Irish, ${ }^{46}$ each of which occurs only once. ${ }^{47}$ However, if any generalizations are to be made, the focus should be on those dyads that occur fairly often. There are three of these that account for $70 \%$ of the treaties in this multi-text category:

$\begin{array}{ll}\text { English/French: } & 43 \text { occurrences } \\ \text { French/Portuguese: } & 18 \text { occurrences } \\ \text { French/Spanish: } & 39 \text { occurrences }\end{array}$

Looking first at the English/French dyad, more than half of these treaties have the United States or the United Kingdom as one party. Evidently, English was used to accommodate them along with French in its role as lingua franca. Typical examples here are the 1923 Agreement between the United States and the Netherlands, ${ }^{48}$ the 1930 Agreement between the United States and Greece, ${ }^{49}$ and the 1967 Agreement between the U.K. and Yugoslavia. ${ }^{50}$ Although the overall incidence of multi-texted treaties is quite constant over the fifty-year period, the treaties involving the United States and the United Kingdom occurred mostly before World War II, indicative probably of a wider lingua franca role for English after World War II. The French/Portuguese dyad consists of treaties between Portugal or Brazil and European countries.

44. Customs Treaty, Nov. 12, 1928, China-Nor., 87 L.N.T.S. 381.

45. Agreement on Economic and Technical Cooperation, June 2, 1961, U.S.S.R.Italy, 457 U.N.T.S. 263.

46. Exchange of Notes Constituting a Trade Agreement, Dec. 26, 1951, Ir.Switz., 558 U.N.T.S. 306.

47. This discussion considers only "exceptions," e.g., a treaty between China and the United Kingdom with English and Chinese both as official texts would not be counted.

48. Exchange of Notes Regarding Copyright on Musical Works, Oct. 2, 1922 Apr. 3, 1923, U.S.-Neth., 21 L.N.T.S. 175.

49. Treaty of Conciliation, June 19, 1930, U.S.-Greece, 136 L.N.T.S. 399.

50. Agreement Between the Postal Administration of the UK and the Administration of Posts, Telegraphs, Telephones of the Socialist Federal Republic of Yugoslavia for the Exchange of Money Orders, June, 30, 1967, U.K.-Yugo. 642 U.N.T.S. 325. 
Typical examples, all of which are found in the L.N.T.S., are the 1921 Exchange of Notes between Portugal and Sweden ${ }^{51}$ and the 1932 Exchange between Brazil and Sweden. ${ }^{52}$ The French/Spanish dyad is similar to the French/Portuguese, except that it spans the entire fiftyyear period. Examples are the 1922 Exchange between Spain and Sweden $^{53}$ and the 1961 Exchange between Chile and the Netherlands. ${ }^{54}$

\section{Three Case Studies: Canada, China and Japan}

If a comprehensive system were available to examine treaties, it would be possible to answer virtually any question about them including uses of official text. For example, it is possible to construct a model of language choice and test hypotheses about languages. Since no system now exists, one has to be satisfied with carefully drawn subsets of treaties, such as the group of 3,000 "exceptions" already discussed. Another way of defining subsets is to examine the treaty behavior of individual countries. In some instances, this examination has already been done, most notably with the United States and Germany. It is clear that the United States insists on English in virtually all of its treaties-there was no appreciable change in this posture during the fifty-year period covered in this study. The case of the German language is interesting in that one can see German playing a fairly substantial role through the 1930s, followed by its virtual disappearance thereafter, as the single language of bilateral treaties, save for those instruments between two German-speaking countries.

The three countries selected for "case studies" provide very different contexts for viewing the interplay between language choice and broader sociopolitical forces. In each case, we have examined all bilateral treaties during at least the fifty-year period, ${ }^{55}$ not just the "exceptional"

51. Exchange of Notes Constituting an Agreement Concerning the Exchange of Notification with Regard to Person of Unsound Mind, Sept. 20, 1921, Port.-Swed., 7 L.N.T.S. 143.

52. Exchange of Notes Constituting an Agreement Regarding Reciprocal Assistance to Brazilian \& Swedish Nationals Suffering from Mental Disease, Jan. 27, 1932, Braz.-Swed., 178 L.N.T.S. 119.

53. Exchange of Notes Concerning the Application of the New Spanish Customs Tariff to Merchandise Ordered in \& Coming from Sweden, Dec. 29, 1921, SpainSwed., 9 L.N.T.S. 57.

54. Exchange of Notes Constituting an Agreement Concerning the Abolition of the Travel Visa Requirement, Apr. 7, 1961, Chile-Neth., 453 U.N.T.S. 239.

55. Depending upon the country examined, it was necessary to extend the fiftyyear timespan to accommodate more recent political events. 
cases that have been the focus so far. This increases the information base and provides a different view on the results.

\section{A. Canada}

Canada represents an interesting case study because of a marked change in official policy, i.e., from the mid-1960s onward, bilingualism was taken seriously as official policy by the Canadian federal government. Thus, a change might be expected in official text languages to occur sometime in the 1960s. A Royal Commission report published in 1967 went so far as to tabulate numbers of bilateral treaties between 1928 and 1965. The Commission found that the English language dominated Canadian treaty-making. ${ }^{56}$ However, the report distinguished between agreements and exchanges of notes in a somewhat confusing way. ${ }^{57}$ In addition, some attention has been given to the matter of language of official text in the scholarly literature. Allan Gotlieb's study, which understates the dominance of English in earlier Canadian treaties, commented:

So far as Canadian practice is concerned, there is a tendency, in contemporary usage, to pay very strict attention to Canada's bilingual character, perhaps resulting in more stringent practices than are generally found internationally. At one time, the Canadian practice appears to have been to conclude bilateral agreements which were authentic in one of the two official languages, and in particular, English with Englishspeaking countries, and French with French-speaking countries. Exchanges of notes followed in general the usual international practice of being in only one language, English with English-speaking countries and French with French-speaking countries. ${ }^{58}$

Professor Anne Marie Jacomy-Millette dealt somewhat more with political forces at work in determining official texts. She wrote that, earlier in Canadian history, English was the language of most Canadian bilateral treaties. ${ }^{59}$ The policy has changed in more recent years:

However, there has recently been a new tendency in this respect, in line with the bilingual policy introduced at the

56. Report of the Royal Commission on Bilingualism and Biculturalism, Book I, The Official Languages 64-65 (1967).

57. Id.

58. Allen Gotlieb, Canadian Treaty-Making 70-71 (1968).

59. Anne Marie Jacomy-Millette, Treaty Law in Canada 60 (1975). 
federal level, first by the government of Mr. Pearson, and since June 1968, that of Mr. Trudeau. Generally the official text of bilateral treaties involving Canada is now in two versions, French and English, equal in authenticity, even where the agreement was concluded with English-speaking countries such as the United States. Use of both official languages for the text of agreements is also the rule with the majority of exchanges of notes or letters. ${ }^{60}$

According to Jacomy-Millette, before the 1960 s, it was not uncommon to find English used in exchanges of notes even with French-speaking countries. ${ }^{61}$

In order to be certain of finding treaty-based evidence of official bilingualism, the article extends coverage through the mid-1970s. Since Canada is an active treaty maker, there is a sizable number of treaties from which to draw conclusions: 453 with signature dates ranging from 1907 through $1977 .{ }^{62}$ First the overall picture and then a few interesting examples will be discussed. The most telling finding is that $95.6 \%$ (433) of these treaties have English as an official text, whereas only $32.7 \%$ (148) have French. Figure 3 shows the proportion of treaties falling into each language category: English-Other; English-French; English only; and French only-as well as the absolute numbers of treaties in each language category (the small numbers atop the bars).

For Canada, the most telling question is the degree of change in use of official texts over time. French has not quite achieved parity with English in terms of frequency of use, but, as Figure 3 shows, the change in the more recent time period is pronounced. Changes might be particularly apparent in examining Canadian treaties with France and the United States where, one would surmise, pressure would be substantial to defer to the language of the other party. The number of Canada/France bilaterals is too small to permit generalization. However, in the case of the United States, there is such a volume of treaty activity $^{63}$ that trends, if there are any, should be discernible.

60. Id.

61. Id. at 48 .

62. Signature date is the most accurate measure of policy of language since it is unaffected by delays in registering the treaty for publication in the L.N.T.S. or the U.N.T.S. Many of these delays are inexplicable.

63. Peter H. Rohn, Treaty Profiles 80-81, 244-45 (1976). There were 113 bilaterals for the period between 1946 and 1965, the largest dyad for both countries. 

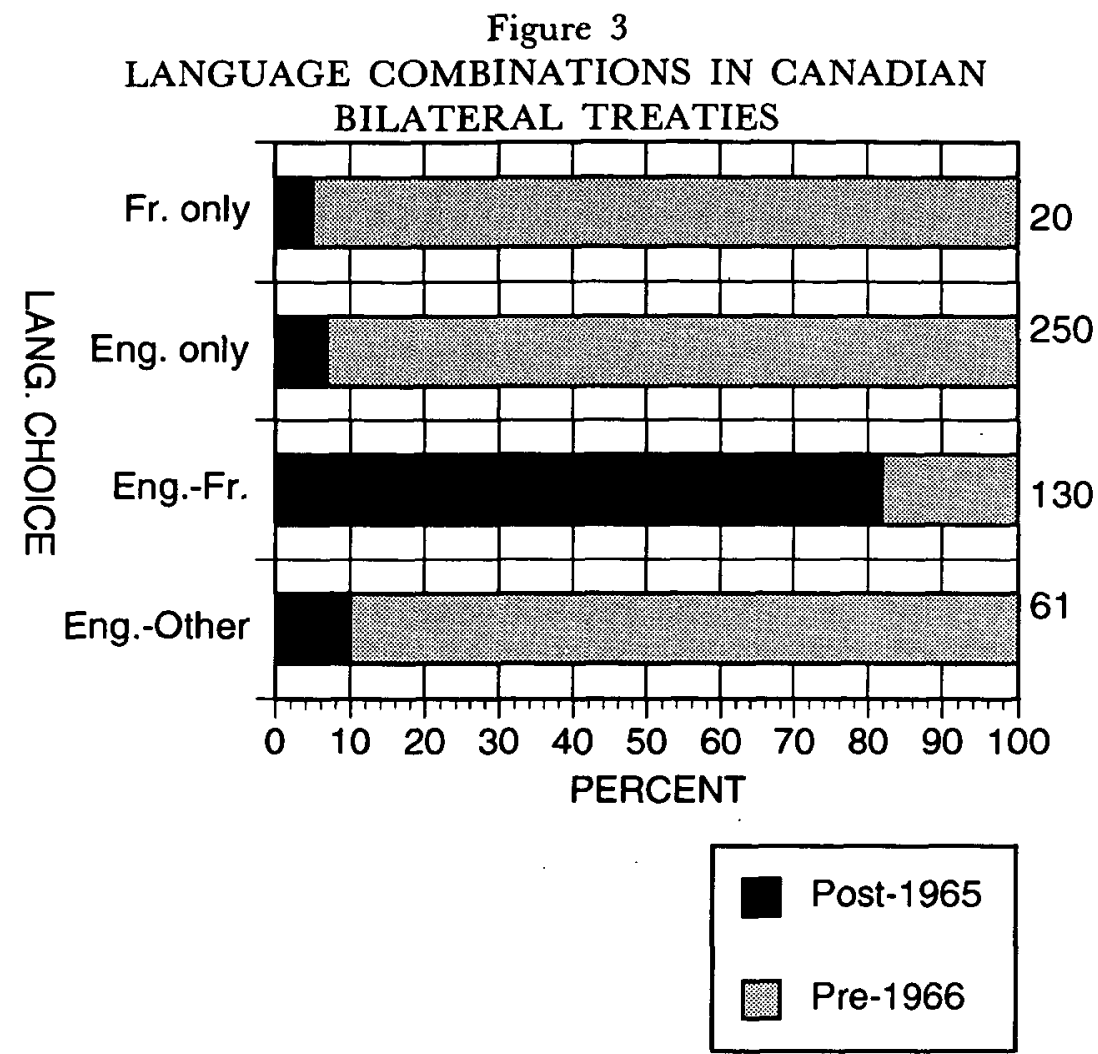

Table $6^{64}$

USE OF ENGLISH AND FRENCH CANADA/U.S.A. BILATERALS

signed before 1966

signed after 1965

\begin{tabular}{c} 
English \\
\hline 128 \\
48
\end{tabular}

\begin{tabular}{c} 
French \\
\hline 2 \\
36
\end{tabular}

The contrast shown by Table 6 could hardly be greater. Before 1966, a bilateral treaty between Canada and the United States had less than a $2 \%$ chance of having French as one of the official texts. After 1965 , and the introduction of clear new policies on bilingualism, three quarters of the treaties used both English and French. These findings

64. Use of percentages in tables like this one would be confusing because of double counting, i.e., a treaty using both English and French would count in both the French and English columns. 
are clear evidence of political forces affecting behavior manifested in international law.

Now that bilateral treaties as a whole have been described, this article will discuss some of the individual treaties. Before 1950, most Canadian treaties used only English as official text, unusual and notable because, at this time, French dominated as a treaty language. French, however, was used in a few instances. For example, treaties with French speaking countries occasionally included both French and English as official texts, e.g., the 1922 Convention between Canada and France, ${ }^{65}$ the 1937 Agreement between Canada and Haiti, ${ }^{66}$ and the 1946 Exchange of Notes between Belgium and Canada. ${ }^{67}$ There are, literally, only several examples where French is the sole official text. These seem to be of two varieties, i.e., treaties with France such as the 1947 Exchange on War Damage Compensation, ${ }^{68}$ and a few cases where Canada conformed to normal practice at the time, e.g., the 1926 Agreement with Norway. ${ }^{69}$ This limited use of French should be seen in the context of dozens of bilaterals with the United States, almost none of which used French. In fact, it is not until 1962 that the first bilateral between Canada and the United States with both English and French as official texts was signed. ${ }^{70}$

The post-1965 situation finds both English and French used in most treaties. The exceptions are a dozen or so bilateral treaties with the United States where only English is used. This period saw a significant increase in treaties with three official texts. If one party insists on more than one official text, that seems to open the door to official texts for all languages of both parties. For example, the 1966 Convention for the Avoidance of Double Taxation ${ }^{71}$ between Canada and Norway has English, French, and Norwegian as official texts. In

65. Commercial Convention, Dec. 15, 1922, Can.-Fr., 21 L.N.T.S. 38.

66. Agreement, Apr. 23, 1937, Can.-Haiti, 224 L.N.T.S. 59.

67. Exchange of Notes Constituting an Agreement Concerning Settlement of War Claims, July 13, 1946, Belg.-Can., 230 U.N.T.S. 159.

68. Exchange of Notes Constituting an Agreement on War Damage Compensation, May 5, 1947, Can.-Fr., 231 U.N.T.S. 81.

69. Agreement Concerning Exchange of Postal Parcels, Apr. 30, 1926, Can.Nor., 51 L.N.T.S. 203.

70. Interim Agreement Relating to General Agreement on Tariffs \& Trade, Mar. 7, 1962, Can.-U.S., 436 U.N.T.S. 3.

71. Convention for the Avoidance of Double Taxation and the Prevention of Fiscal Evasion with Respect to Taxes on Income, Nov. 23, 1966, Can.-Nor., 604 U.N.T.S. 295. 
the 1967 Cultural Agreement, ${ }^{72}$ Canada and Belgium use Dutch, English, and French. This practice is different from that of the 1920's, when they likely would have used French only, an official language in both countries. Later, the article discusses the implications of this "inflation" in the number of languages.

\section{B. China}

China presents a vastly different situation from that encountered with Canada. One of the earliest Chinese treaties, the 1689 Treaty between China and Russia, was written in Latin, the norm for that time, and was negotiated through intermediaries (Catholic priests) ${ }^{73}$ Any discussion of Chinese treaty-making must consider the nature of Chinese treaty relations as they developed in the 19th century. These relations were characterized by Western powers and Japan using treaties with China to maintain diplomatic, commercial, and political privilege. These foreign powers assumed responsibility for implementing treaties within China. ${ }^{74}$ Given this context, language choice surely was influenced. However, interpreting the use of official texts in 19th century treaties presents certain difficulties. Treaty series often did not specify official texts. Further, a widespread practice of 20th century treatiesincluding an explicit textual statement about authentic texts-was not used in 19th century Chinese treaties.

Even given the above limitations, a reasonable estimate can be made that the Chinese language was used in about one third of 19th century Chinese treaties. For example, the 1842 Treaty between China and Great Britain $^{75}$ and the 1844 Peace Treaty ${ }^{76}$ between China and the United States used Chinese and English. Many other treaties used only English, e.g., the 1872 Treaty between China and $\operatorname{Japan}^{77}$ and the 1894 Convention with the United States. ${ }^{78}$ A few treaties followed the mode of the times, using French as lingua franca, e.g., the 1844 Treaty of Friendship, Com-

72. Cultural Agreement, May 8, 1967, Can-Bel., 637 U.N.T.S. 217.

73. Treaty, Oct. 1689, China-Russia, 18 C.T.S. 503.

74. See Treaties and Agreements With and Concerning China, 1894-1919 (John V.A. MacMurray ed. 1921); M.T.Z. Tyau, The Legal Obligations Arising of Treaty Relations Between China and Other States (1917).

75. Treaty, Aug. 29, 1842, China-U.K., 93 C.T.S. 465 .

76. Treaty of Peace, Amity \& Commerce, July 3, 1844, China-U.S., 97 C.T.S. 105.

77. Treaty of Commerce \& Navigation, 1868, China-Japan, 144 C.T.S. 139.

78. Convention Regulating Immigration, Mar 17, 1894, China-U.S., 180 C.T.S. 
merce and Navigation with France. ${ }^{79}$ One of the very few explicit textual references to languages and language issues was contained in the 1899 Agreement between China and Germany, a treaty that appears to have been written in German: "Article IV. All correspondence between the Customs Office at Tsiutan and the German authorities and German merchants shall be conducted in the German language. . . Correspondence in Chinese shall be likewise permitted." 80

The period between 1920 and 1980 saw the end of an era of Western influence in China followed by a civil war and, ultimately, the bifurcation of Chinese treaty-making. Thus, it is important to compare pre-1949 treaty behavior with that of Beijing and Taipei after 1949. Figure 4 provides a broad view of language use in Chinese treaties.

Figure 4

USE OF LANGUAGE IN THE TREATIES OF

PRE-1949 CHINA, TAIWAN, and P.R.C.

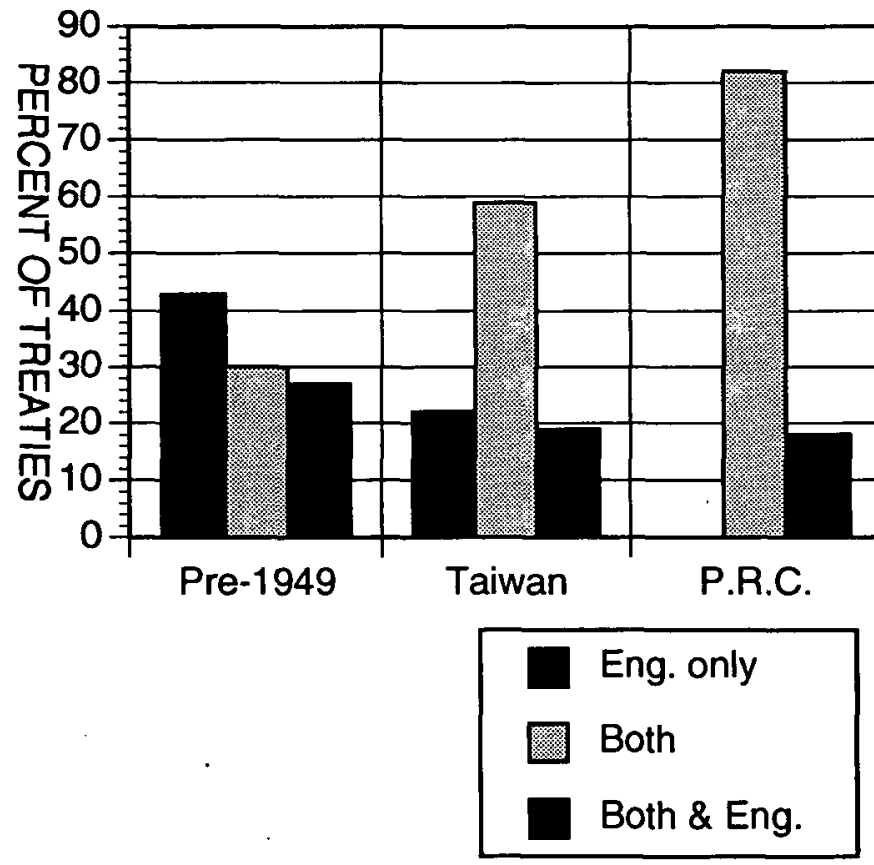

79. Treaty of Friendship, Commerce \& Navigation, Oct. 24, 1844, China-Fr., 97 C.T.S. 375.

80. Agreement Respecting the Establishment of a Maritime Custom Office at Tsintaw, Apr. 17, 1899, China-Germany, 187 C.T.S. 383. 
Figure 4 uses three main language categories - English only; Chinese and the language of the other party; and Chinese, the language of the other party, and English. Several points stand out about the period before 1949 (summarized in the leftmost portion of Figure 4). First, there is not a single treaty with Chinese as the only official text. Although the same may be true for Hungarian, Finnish, Urdu, and Irish, Chinese was used by more people than any other language in the world. Thirty-two from a total of 75 treaties have only one official text and more than $90 \%$ of the official texts are English. English was used as the only official text with many different parties including Japan, ${ }^{81}$ the Soviet Union, ${ }^{82}$ the United Kingdom, ${ }^{83}$ and Italy. ${ }^{84}$ The other unilingual treaties used French and commonly were with Switzerland. ${ }^{85}$

Somewhat more than half (43) of these 75 treaties have two or more official languages. The pattern is very clear in showing that virtually all of this subset uses English as one of the official texts. If the treaty is between China and an English-speaking country, ${ }^{86}$ the official texts are Chinese and English. If the party is not an English-speaking country, English is still used, making a total of three official texts. This pattern holds across the entire range of languages including treaties with Japan, ${ }^{87}$ Austria, ${ }^{88}$ Portugal, ${ }^{89}$

81. Treaty for the Settlement of Outstanding Questions Relative to Shantung, Feb. 2, 1922, China-Japan, 10 L.N.T.S. 309.

82. Agreement for the Provisional Management of the "Chinese Eastern Railway," with Declaration for the Regulation of the Situation Created for the Russian Citizen in Pursuance of the Principle of Equal Representation of Citizenship of the Two Countries on the Staff of the "Chinese Eastern Railway," May 31, 1924, ChinaU.S.S.R., 37 L.N.T.S. 193.

83. Agreement Between the Post Office of North Borneo and the Post Office of China for the Transaction of Money Order Business, July 17, 1936, China-U.K., 173 L.N.T.S. 343.

84. Exchange of Notes of the Settlement of the Claims for Damages Arising out of the War, July 30, 1947, China-Italy, 12 U.N.T.S. 377.

85. See, e.g., Agreement with Regard to the Traffic in Narcotic Drugs Between the two Countries, Apr. 12, 1927, China-Switz., 66 L.N.T.S. 427.

86. See, e.g., Parcel Postal Agreement Between China \& Ceylon, Dec. 8, 1922, China-U.K.-Ir., 137 L.N.T.S. 319.

87. Agreement Concerning the Exchange of Inserts, Letters \& Boxes Between the Two Countries, Dec. 8, 1922, China-Japan, 20 L.N.T.S. 233.

88. Treaty, Oct. 19, 1925, China-Aus., 55 L.N.T.S. 9.

89. Preliminary Treaty of Amity \& Commerce, Dec. 1928, China-Port., 107 L.N.T.S. 93. 
Sweden, ${ }^{90}$ Thailand, ${ }^{91}$ Ecuador, ${ }^{92}$ and the Netherlands. ${ }^{93}$

Another view of Chinese treaty-making in this earlier period comes from inquiring into what portion of Chinese treaties, signed between 1920 and 1948, had Chinese as an official text. The answer is $56 \%$, compared to $84 \%$ for English as an official text. Notwithstanding arguments in favor of English as an international language, one can imagine how this dominance of English over Chinese could create feelings of neocolonialism and linguistic hegemony.

The post- 1949 period provides the opportunity to compare the behavior of two Chinese states, each with many treaty commitments. The practice followed by the People's Republic of China (hereinafter China or PRC) showed a marked change. All 41 treaties of the PRC used Chinese as one official language. The norm was Chinese and the language of the other party. There are a few tri-lingual treaties. A 1951 Agreement between China and Poland used Chinese, Polish, and Russian. ${ }^{94}$ Perhaps reflecting the deterioration in Sino-Soviet relations, a 1960 Treaty between Czechoslovakia and PRC used only Chinese and Czech. ${ }^{95}$ In a very few cases, English was used, but only along with Chinese and the language of the other party, e.g., a 1974 Agreement on Maritime Transport with Denmark with Chinese, Danish, and English as official texts. ${ }^{96}$ Possibly, the use of English in this treaty resulted from a combination of a relatively sympathetic Western party and little knowledge of Danish in the Chinese foreign ministry.

The use of official languages by the Republic of China (hereinafter Taiwan) also shows a dramatic change from the pre-revolution period. Taiwan, like the PRC has adopted Chinese as an offical text. Some exceptions exist, such as French being the sole official text ${ }^{97}$ and 17 treaties, mostly with the United States, in which only English is used. Unlike the PRC treaties, however, Taiwan often used English as a third language along with the national languages of both parties, e.g.,

90. Treaty Regulating Tariff Relations Between the Two Countries, Dec. 20, 1928, China-Swed., 107 L.N.T.S. 81.

91. Treaty of Amity, Jan. 23, 1946, China-Thail., 161 U.N.T.S. 127.

92. Treaty of Amity, Jan. 6, 1946, China-Ecuador, 7 U.N.T.S. 233.

93. Air Transport Agreement, Dec. 6, 1947, China-Neth., 43 U.N.T.S. 185.

94. Agreement Concerning Cultural Co-operation, Apr. 3, 1951, P.R.C.-Pol., 304 U.N.T.S. 187.

95. Consular Treaty, May 7, 1960, P.R.C.-Czech., 402 U.N.T.S. 209.

96. Agreement on Maritime Transport, Oct. 21, 1974, Den.-P.R.C., 991 U.N.T.S. 15.

97. Exchange of Notes Constituting a Provisional Agreement Concerning Civil Air Transport, July 19, 1963, P.R.C.-Belg., 564 U.N.T.S. 23. 
treaties with Spain, ${ }^{98}$ Turkey, ${ }^{99}$ and the Republic of Korea. ${ }^{100}$ Taiwanese treaty activity diminishes substantially after the mid-1970s. However, there is some indication of a shift back towards the use of English as the only language, likely a result of feelings of isolation resulting from the widespread recognition of the PRC as the official representative of China.

Overall, the use of official texts in Chinese treaties seems to reflect nationalism, but differently than might be imagined. Similarly, the forces of nationalism are manifest in the treaties of the PRC and of Taiwan. This is evidence of the dominance and durability of nationalism over more transient political ideologies.

\section{Japan}

The international legal scholarly literature, at least that available to us in North America, mentions little about Japanese policy or behavior in choice of official text languages in bilateral treaties. Adams provided a general description of the behavioral side of choosing official text:

English is the most frequently used language as an official language occurs, first, where it is the only language stated as being official and, second, in instances where three languages are designated and English is designated to prevail in the event of a dispute. These latter agreements usually are written in Japanese, the language of the co-signatory and English. In some instances, English and Japanese are recognized as being equally authentic, most notably in treaties with the United States, the United Kingdom and Canada. Finally, in instances where English is not used as the official language, French is the most prevalent language used. ${ }^{101}$

The practice of Japan in treaty languages should be especially interesting for two reasons. First, it can be a test of whether the changes in the use of English and French hold up in a non-Western context. It is entirely possible that the dominance of French as lingua franca in diplomacy and treaty-making is a remnant from the age of Euro-centric

98. Treaty of Amity, Feb. 19, 1953, P.R.C.-Spain, 181 U.N.T.S. 81.

99. Cultural Convention, Feb. 12, 1957, P.R.C.-Turk., 282 U.N.T.S. 125.

100. Treaty of Amity, Nov. 27, 1964, P.R.C.-Korea, 555 U.N.T.S. 3.

101. L. Jerold Adams, The Theory, Law and Policy of Contemporary Japanese Treaties 41 (1974). 
international law. Perhaps these behaviors did not extend beyond Europe and its colonial umbrella. Second, it would be interesting to examine whether Japan's subjugation following World War II is reflected in treaty behavior. One might hypothesize that the Japanese language, as a symbol of militarism, would have been used less, especially immediately after 1945 .

Table 8

NUMBER OF OFFICIAL TEXTS BY TIME PERIOD

$\begin{array}{lllr} & \text { ONE } & \text { TWO } & \underset{>2}{2} \\ \text { UNTIL 1945 } & 56(79 \%) & 10(14 \%) & 5(7 \%) \\ 1946-1959 & 66(47 \%) & 65(48 \%) & 8(5 \%) \\ 1960-1974 & 69(43 \%) & 79(49 \%) & 13(8 \%)\end{array}$

Clearly, there has been a substantial change in Japanese practice. In the pre-war period, about four-fifths of Japanese treaties had only one official text. Since World War II, almost half have had two official texts. The use of English and French in those treaties with only one official text has changed significantly over the three time periods considered.

\section{Table 9}

USE OF ENGLISH AND FRENCH IN UNILINGUAL TREATIES

$\begin{array}{ccc} & \underline{\text { English }} & \underline{\text { French }} \\ \text { until } 1945 & 34(61 \%) & 22(39 \%) \\ 1946-1959 & 53(80 \%) & 10(15 \%) \\ 1960-1974 & 67(97 \%) & 2(3 \%)\end{array}$

The diminution in the use of French is comparable in degree to that observed for the entire world. The difference stems from the fact that French never achieved the widespread use in Japanese treaties it enjoyed in most of the world.

The anticipated change in language behavior after World War II is not seen in these data, at least not in an unequivocal way. The Japanese language was used in a much higher percentage of these treaties in the immediate post-war period than in the period between 1920 and 1945. One way to focus on any changes that may have occurred is to examine United States-Japanese bilateral treaties. In all except the first time period, there were large numbers of these treaties 
from which to draw conclusions. Not surprisingly, all of these treaties are of one of two language types, English only or English and Japanese.

Figure 5

USE OF ENGLISH AND ENGLISH/JAPANESE IN BILATERAL TREATIES BETWEEN JAPAN AND THE UNITED STATES

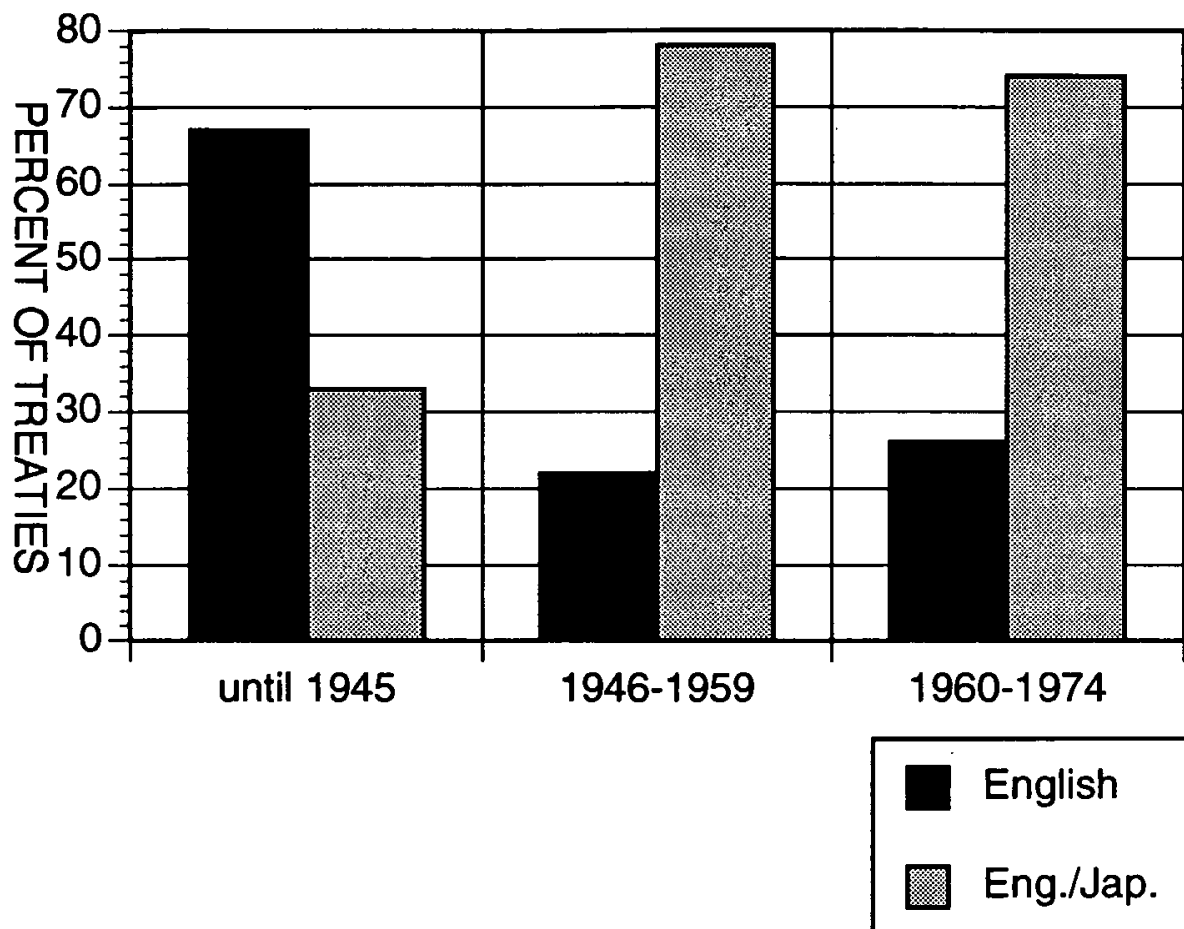

Conclusions based on this information must be tentative. Few treaties existed in the pre-war period. But this began to change in the wake of World War II with Japanese being used as one official text in most treaties. The most recent time interval shows some shift back towards English - the amount of that shift is small $(4 \%)$ and would be unremarkable were it not for half of the most recent treaties, i.e., 6/13, signed from 1971-1974, using English exclusively. One possible explanation is that the wider use of the Japanese language was a point of honor immediately after the war that eventually gave way to expediency, as Japan participated more actively in a global economy dominated by the English language.

Some examples of specific Japanese treaties that fall into these categories follow. During the first time period, 1919-1945, most Japanese treaties had only one official text, usually English. Not surpris- 
ingly, English was used in treaties with the United States ${ }^{102}$ and the United Kingdom. ${ }^{103}$ English was the only official text in treaties with Poland, ${ }^{104}$ the Soviet Union, ${ }^{105} \mathrm{Cuba},{ }^{106}$ and Thailand. ${ }^{107}$ French was used mostly in treaties with European countries, including the Netherlands, ${ }^{108}$ Norway, ${ }^{109}$ and Finland. ${ }^{110}$ During this period, virtually all Japanese treaties with China had three official texts, invariably using English as a third language. ${ }^{11}$

The post-war treaties show less variety with only one dominant mode, i.e., Japanese and the language of the other party. There are a few cases where French remains the sole language, e.g., the 1953 Note with France ${ }^{112}$ and a 1956 Exchange of Notes with Italy. ${ }^{113}$ There are many examples of English as the only official text. Most of these are with the United States, but English also was used exclusively in

102. See, e.g., Treaty Concerning the Yap Island and the Other Islands Under Mandate Situated in the Pacific North of the Equator and Exchange of Notes Relating Thereto, Feb. 11, 1922, U.S.-Japan, 12 L.N.T.S. 201; Exchange of Notes Constituting an Agreement Regarding the Development of Certain Portions of the Great Lakes-St. Lawrence Basin Project, Oct. 14, 31 \& Nov. 17, 1940, U.S.-Japan, 101 L.N.T.S. 63.

103. See, e.g., Exchange of Notes Respecting the Obligation of Article 8 of the Treaty of Commerce \& Navigation, June 14, 1924, Japan-U.K., 28 L.N.T.S. 538; Convention for the Prevention of Smuggling of Intoxicating Liquors, Nov. 7, 1940, Japan-U.K., 203 L.N.T.S. 267.

104. Treaty of Commerce \& Navigation, Dec. 7, 1922, Japan-Pol., 32 L.N.T.S. 61 .

105. Convention Embodying Basic Rules of the Relations Between Japan and the Union of Soviet Socialists Republic, Together with Protocols A and B, Declaration, Exchange of Notes, Annexed Note and Protocol of Signature, Jan. 20, 1925, JapanU.S.S.R., 34 L.N.T.S. 31.

106. Exchange of Notes Constituting a Provisional Commercial Agreement, Dec. 21, 1929, Japan-Cuba, 111 L.N.T.S. 13.

107. Treaty Concerning the Continuance of Friendly Relations Between the Two Countries and the Mutual Respect of Each Other's Territorial Integrity, June 12, 1940, Japan-Thail., 204 L.N.T.S. 131.

108. Treaty, Oct. 12, 1921, Japan-Neth., 12 L.N.T.S. 239.

109. Exchange of Notes Constituting an Arrangement Concerning the Exchange of Notifications with Regard to Persons of Unsound Mind, Oct. 23, Nov. 6, 1923, Japan-Nor., 33 L.N.T.S. 265.

110. Exchange of Notes Regarding the Abolition of Passport Visas Between the Two Countries, Feb. 25, 1928, Fin.-Japan, 71 L.N.T.S. 467.

111. See, e.g. Agreement Concerning the Exchange of Correspondance Between the Two Countries, Dec. 8, 1922, P.R.C.-Japan, 20 L.N.T.S. 205.

112. Peace Treaty, Apr. 25, 1953, Japan-Fr., 187 U.N.T.S. 41.

113. Exchange of Notes Constituting an Arrangement Concerning the Abolition of Visas on Passports, Jan. 11, 1956, Japan-Italy, 267 U.N.T.S. 175. 
treaties with Sweden, ${ }^{114}$ Turkey, ${ }^{115}$ Czechoslovakia, ${ }^{116}$ and Argentina. ${ }^{117}$

\section{Conclusions}

This survey of language choice in bilateral treaties has produced results that should be of interest along several dimensions. It provides a precise description of broadly based state practice in the bilateral aspect of treaty-making. Three prevalent generalizations about treaty making are confirmed:

1) there is no international law standard about use of official texts;

2) English now dominates treaty-making as French once did; and

3) modern practice tends to use the language of both parties as official texts.

Although all three are true, they are too broad to describe, much less to explain, state behavior. The absence of an international law standard hardly obviates the need to understand practice. Neither of the other two assertions is an ironclad rule-it is important to know the degree to which English now dominates and what portion of recent treaties use the languages of both parties. English is now the diplomatic language, although French has been more resilient than many would have believed. The issue of the utility of French language ability resurfaced during the informal negotiations that, ultimately, led to the selection of Boutros Boutros-Ghali as UN Secretary-General. ${ }^{118}$

In many instances, choice of language reflects political forces, most notably, nationalism or international status in this aspect of treaty behavior. German has all but disappeared as a lingua franca. The Soviet Union and the Russian language are the exception-there was virtually no tendency for the rise of the U.S.S.R. as a superpower to be

114. Convention for the Avoidance of Double Taxation and the Prevention of Fiscal Evasion with Respect to Taxes on Income, Dec. 12, 1956, Japan-Swed., 318 U.N.T.S. 309.

115. Exchange of Letters Constituting an Arrangement Concerning the Mutual Abolition of Passport Visas, Nov. 5, 1957, Japan-Turk., 318 U.N.T.S. 411.

116. Treaty on Commerce, Dec. 15, 1959, Japan-Czech., 383 U.N.T.S. 277.

117. Exchange of Notes Constituting an Agreement Concerning Reciprocal Waiving of Passport Visas, Dec. 26, 1961, Japan-Arg., 451 U.N.T.S. 71.

118. See Paul Lewis, Africans Pressing Bid for U.N. Post Say Next Chief Must Be From Their Continent and Warn of Clash at Assembly, N.Y. Times, Oct. 22, 1991, at A11; Judith Miller, A Born Secretary General, N.Y. Times, Nov. 22, 1991, at A12. 
accompanied by increased use of the Russian language. In the case of Canada, domestic policy changes in the form of official bilingualism explain the behavior. The treaty practices of China and Japan indicate that both national pride and convenience are factors in language choice.

It is hoped that this research will stimulate further efforts to show how information basic to international law-treaty attributes in this case-can be a meaningful indicator of state behavior. A disappointing development in academic international law circles over the last quarter century is the abandonment of international law by mainstream political science. ${ }^{119}$ One of the main reasons offered for this change is international law's inability to use the quantitative techniques widely applied in political science since the 1960s. These treaties provide one concrete example of how phenomena of interest to international lawyers can be meaningful indices of national behavior of the sort in which political scientists should be very interested. ${ }^{120}$ In fact, the care with which international law experts are taught to approach their work increases the likelihood that the data collected will be meaningful, sensitive indicators of behavior.

The patterns in language choice uncovered by this research can be viewed in a broader context. There is an interesting and rapidly expanding trend of literature in political science and psychology dealing with language problems, especially within multilanguage societies. A major problem is balancing the competing values of simplicity and efficiency against the often emotional feelings individuals and whole groups have for national languages. The logical solution is an easy-tolearn artificial language. The advantages of an artificial language are significant:

1. learnable (because of grammatical and lexical regularity);

2. powerful (having true-to-nature terminologies, logical structures, and freedom from idiomatic restrictions); and,

3. fair (having no native speakers). ${ }^{121}$

The most successful of these, Esperanto, never achieved any level of proficiency by more than one person in a thousand, ${ }^{122}$ and has never

119. For a wide ranging discussion, see Charlotte $\mathrm{Ku}$ (chair), Bridging the Gap Between Political Scientists and Lawyers, 81 ASIL Proceedings 1987 381, $381-394$ (1990).

120. Twenty years ago, Harold Lasswell made these same points, but almost no one listened. See Michael Barkun \& Wesley B. Gould, International Law and the Social Sciences (XV-XX by Harold D. Lasswell 1970).

121. Jonathan Pool, The World Language Problem, 1 Univ. of Wash.: Language and Soc'y Papers \# LD2 (1990), reprinted in Rationality AND Society 1991.

122. Peter G. Forster, The Esperanto Movement $1-3$ (1982). 
been used in either the L.N.T.S. or the U.N.T.S. It appears that the international community will have to endure continued use of more official texts-on the part of states. One of our most striking findings is the huge increase in average number of texts used from the League of Nations to the United Nations. The statistics may be sterile, but they paint a clear picture. L.N.T.S. treaties averaged about 1.6 official texts, while U.N.T.S. treaties average about 2.0 texts per bilateral treaty. Faced with the combination of perceptions of linguistic imperialism" ${ }^{123}$ and feelings that every national language has "a basic right to its possession and, if necessary, its defence,",124 there probably will be further increases in the number of languages used. It is possible to develop theoretical solutions to try to curb the cumbersome use of several official texts. One commentator suggests a tax or subsidy according to ease or difficulty in operating with languages. ${ }^{125}$ Although an interesting idea, it is fraught with political and operational problems.

Professor Manley O. Hudson, in a seminar he conducted at Harvard Law School in 1932, asked each class member to examine official texts used in the treaties of her/his country for the period January 1, 1921 - December $31,1930 .{ }^{126}$ Although the class analyzed the treaties of only twelve countries, ${ }^{127}$ their findings are consistent with those discussed here. Hudson realized the shortcomings of his study noting that "the limited number of treaties considered does not permit a final and general conclusion to be drawn." 128 Sixty years later, the research for this article has met Professor Hudson's objection.

Many possibilities exist to broaden the applicability and increase the elegance and parsimony of this research. There are prospects for using the broad contours developed here to examine more concrete matters:

- How has the World Court dealt with issues of language and official text;

-Do third languages used in treaties relate to substantive treaty provision, e.g., the guarantor role of third parties;

123. TABORY, supra note 9 , at 5 .

124. Peter L. Berger, Facing Up to Modernity 161(1979).

125. Jonathan Pool, The Official Language Problem, 85 Amer. Pol. Sci. Rev. 495, 498-502 (1991).

126. Hudson, supra. note 19 , at 370 .

127. Id. at 370-72 - China, Colombia, France, Germany, Hungary, Italy, Japan, Peru, Poland, Switzerland, the United Kingdom, and the United States.

128. Id. at 372 . 
-Does language choice affect the probability of treaty compliance?

Language choices in certain multilateral treaties might be examined. One could learn little from general multilateral treaties, since almost all of them now employ all six languages of the United Nations as official texts; but plurilateral treaties are more interesting. For example, the five Scandinavian countries often negotiate pentalingual treaties. ${ }^{129}$ Putting aside intraregional politics, it would be much simpler if English were used exclusively, especially since all five use English often in their other treaty relations. This exclusive use of English would seem all the more rational since, if one exceeds three languages, complexities and problems seem to escalate. ${ }^{130}$ Maybe it is time to consider radical solutions like a linguistic difficulty supplement or tax.

There can be no doubt that huge amounts of resources are used for everything from foreign office personnel to library budgets because of growing sensitivity about the use of national languages. Maybe this is another area where some curbs on nationalistic forces might be considered. An alternative view holds that the widespread use of bilingual and trilingual treaties might be a small price to pay if it were to improve, even marginally, the likelihood of agreement on substantive treaty provisions. Given the large number of possible languages which could be used in treaties, coupled with the increasing number of technical subjects covered by treaties, language choice remains an important consideration as the world strives for greater equality and order through increased clarity and compliance in treaty relations.

129. See, e.g., Convention Respecting the Application of the Accident Insurance Laws of the Various States to Cases where an Employer in Lieu of the Contracting States Carries on a Business or Employs Workers in Another of the Said States, March 3, 1937, 182 L.N.T.S. 127.

130. Heinz Kloss, Types of Multilingual Communities, in Explorations in SocioLinguistics 7 (Stanley Lieberson ed. 1966). 